\title{
Japan's Challenges on Muslim Friendly Tourism to Attract Muslim Tourists 2013-2019
}

\author{
Sandyka Kurniawan \\ Universitas Muhammadiyah Yogyakarta \\ Email:sandykakur@gmail.com \\ Sidik Jatmika \\ Universitas Muhammadiyah Yogyakarta \\ Email:dr.sidikjatmika@gmail.com
}

\begin{abstract}
Tourism is now a part of the modern lifestyle. Infrastructure, technology, and information are developing, making it easier for individuals to go abroad. When traveling, each individual brings identity and need. In Islam, Muslims have a role in tourism because Islam for Muslims is a lifestyle. Tourism in Islam is called halal tourism, a new phenomenon, and a new business opportunity, targeting Muslim tourists. Japan is a non-Muslim country and is not based on Islamic values. Of course, it will be a challenge for Japan to understand halal tourism. Japan is well known for its services, products, and facilities. Japan has been preparing for halal tourism well, introducing itself as the world's best tourist destination and host for the 2021 Olympics. The authors used qualitative methods, observation, and literature study. The final results of this study are expected to provide awareness of the importance of tourist destinations that are friendly to Muslims and offer new economic opportunities in the tourism sector.
\end{abstract}

Keywords: Tourism, Japan, Halal

\section{Abstrak}

Pariwisata sekarang hari adalah bagian dari gaya hidup modern. Dukungan infrastruktur, teknologi, informasi semakin memudahkan mobilitas individu maupun kelompok. Tidak dapat dipungkiri bahwa individu atau kelompok ini dalam perjalanannya membawa suatu identitas dan juga kebutuhan. Dalam 
agama Islam, Islam memiliki peranan dalam wisata, karena agama Islam bagi umat Muslim adalah sebuah gaya hidup. Pariwisata dalam Islam dikenal juga sebagai pariwisata halal yang merupakan fenomena baru dan peluang bisnis baru dalam dunia pariwisata yang menargetkan wisatawan muslim sebagai pasar. Jepang adalah negara Non-Muslim dan tidak berlandaskan nilai-nilai Islam, tentunya akan menjadi tantangan dan hal yang baru bagi Jepang dalam memahami pariwisata halal. Jepang dikenal baik dalam pelayanan, produk dan fasilitas, tentunya memunculkan pertanyaan apakah Jepang yang merupakan negara Non-Muslim ini mempersiapkan dengan baik pariwisata halal, mengingat Jepang ingin mengenalkan dirinya sebagai destinasi wisata terbaik dunia serta sebagai tuan rumah untuk Olimpiade 2021. Dalam penulisan ini penulis menggunakan metode kualitatif, observasi dan studi pustaka. Hasil akhir dari penelitian ini diharapkan dapat memberikan kesadaran akan pentingnya destinasi wisata yang ramah bagi umat Islam, serta memberikan peluang dan peluang ekonomi baru di bidang pariwisata.

Kata Kunci: Pariwisata, Jepang, Halal

\section{INTRODUCTION}

The development of infrastructure in a country, technology, and information is fast to make individuals' or groups' mobility easier. In this digital era, increasing middle-class economic growth and social media also affect different patterns of individuals or groups. One of the most important patterns of change in the field of tourism. Social media not only introduces but also motivates these individuals or groups to travel to these places. According to UNWTO, tourism is a social, cultural, and economic phenomenon that entails the people's movement to countries or areas outside their usual environment for personal or business / professional purposes. These people are called visitors (which may be either tourists or excursionists; residents or nonresidents), and tourism has to do with their activities, some of which imply tourism expenditure (Charles R. Goeldner, 2009).

Tourism religious and spiritual motivation has become widespread and popular in recent decades, occupying an essential segment of international tourism substantially in recent years. Religious tourism 
is one of the less-studied topics in tourism research (Dallen J. Timothy, 2006). Timothy and Olsen explained that an increase in tourists with religious motivations attracted academia, government, and tourism agencies to develop tourism. This religious travel is associated with the place inside the Holy Quran (Namin, 2013), the Bible, and other sacred texts.

Tourism itself is one of seven sectors in the Islamic economy with a significant role other than halal culinary, fashion, cosmetics, pharmaceuticals, entertainment, insurance, and Islamic finance (Thomson Reuters, 2016). Halal tourism has recently gained popularity and is now becoming a new phenomenon in the tourism industry. Halal tourism refers to tourism products that provide services with Islamic beliefs and practices.

Tourism is included in the pillars of peace (Peace, 2019). Of course, tourism has a vital role in international relations to show good relations with neighboring countries and political stability. Of course, tourism also has an impact on business, foreign direct investment. Targeting Muslims as a market in tourism is an excellent opportunity for the future and undoubtedly influenced by several factors, such as the growing Muslim population globally, predicted in 2050 to reach 2.8 billion million people. This population also the growth of Muslim millennials and young adults, with some already transiting into parenthood, are shaping the future of tourism and hospitality with their unique service needs. The economic growth of the middle-class people, such as the Gulf countries, Malaysia and Indonesia, are categorized as developing countries. Increased and easy access to information for Muslim tourists is critical because it is related to the choices of Muslim tourists, whether the destination is Muslim-friendly. The increasing Muslim population also increases availability needs, services, and facilities, making a chance more on business, not only for domestic support but also for export opportunities.

This growth can help Japan to meet its target as a world-class tourist destination. Abenomics is the Japanese economic and investment strategy program targeted in the 2020-2030 period. Tourism is one of the pillars for building the Japanese economy, with plans in 2020 to reach up to 40 million foreign tourists and 2020. 2030 is targeted to get 60 million foreign 
tourist arrivals. Japan is planning to achieve the target of 8 trillion yen in 2020 and 15 trillion yen in 2030 against the costs incurred by foreign tourists when traveling to Japan, and 70 million tourists per night in 2020, then 130 million tourists by 2030. Twenty-four million foreign tourists who returned to visit Japan (repeat inbound tourists) in 2020 will increase to 36 million tourists in 2030 and recently achieve the target issued by domestic tourists of 21 trillion yen in 2020 and up to 22 trillion yen in 2030. Japan is not a Muslim country, and Muslims are only a minority there. Of course, in carrying out tourism that targets Muslim tourists, Japan will face challenges in running Muslimfriendly tourism. Islam for Muslims is not only a religion but also a lifestyle. Therefore it is necessary to see the basic understanding and real challenges in carrying out friendly tourism with Muslim tourists.

\section{LITERATURE REVIEW}

Japan, which is not a Muslimmajority country, has challenges in developing Muslim-friendly tourism. To understand Japan's challenges on Muslim-friendly tourism to attract Muslim tourists, the authors conducted a literature review related to previous studies about Muslim-friendly tourism. The first journal entitled Halal Certification and Its Impact on Tourism in Southeast Asia: A Case Study of Halal Tourism in Thailand by Alfian Nurdiansyah (Nurdiansyah, 2018). The author explored the global era and the advancement of the international trade system, market investors to attract new products. Halal products can become new reference points given the increasing number of Muslim populations in the world. The demand for halal products will also increase significantly along with the people.

Second in the journal entitled Halal, New Zealand! An Exploratory Study into the halal-friendliness of Accommodation Providers in New Zealand by Serrin Razzaq, C. Michael Hall, and Girish Prayag (Razzaq, Hall, \& Prayag, 2016). The authors revealed that New Zealand had increasingly promoted itself as a Muslim-friendly destination to attract Muslim tourists. New Zealand's long-time exporter of halal beef and goat is now trying to encourage other forms of halal products. However, providing halal tourism and hospitality and tourism is a much more complicated process than providing halal meat. It requires a nuanced understanding of Islamic 
consumers and their socio-cultural positions and different demands. Third, Majang Palupi, Rizqi Wahyu Romadhon, and Nur Arifan on a journal entitled Importance of Optimization of Halal Tourism: A Study of The Development of Halal Tourism in Indonesia (Palupi, Romadhon, \& Arifian, 2017). This research stated that the development of the halal tourism industry in Indonesia is lagging behind other countries. However, there are factors for booming halal tourism in Indonesia, such as halal accommodation, halal food, drinks availability, and human resources. Besides, the government is advised to implement strategic policies, national branding, and human resource investment.

Fourth, Isa Ma on Halal market in China: Potentials and Challenges (Ma, 2018). This research explained that China could develop the halal market assuming that the Chinese government is probusiness, encouraging political issues and other factors. The factor that determines the potential of the Halal market is the Muslim population in China. The size of the consumer population is significant. The second factor that determines the potential of the Halal market is the purchasing power. Fifth is
Surwandono, Rizki Dian Nursita, Rashda Diana, and Ade Meiliyana on The Discoursing on Halal Tourism Policy in Indonesia and its Review in Maqâshid Syarîah (Surwandono, Nursita, Diana, \& Meiliyana, 2020). Tourism in Indonesia, especially halal tourism, still experiences ambiguity in understanding halal tourism itself. The governance of halal tourism in Indonesia is still not fully following the maqashid Sharia because it only follows trends and reactions that distort the basis of tourism. What happened in Indonesia was different from what happened in East Asia, where East Asia considered this phenomenon an economic phenomenon, not an exclusive identity.

\section{METHODOLOGY}

The study of this paper used observation and interviews from 2018-2019, browsed information sourced from print, electronic media, tourism literature about the development of tourism in the world, and tourism in Islam, described and interpreted the data. In particular, the study of Muslimfriendly tourism as part of a Muslim religious practice will be described based on tourism. 


\section{TOURISM IN RELIGION}

The growing tourism industry will undoubtedly bring up new segments for tourists to fulfill specific targets. For example, in religion and tourism, some do not realize this relationship. Religion is still the most common motivation for traveling (Kreiner \& Wall, 2015). Religiously motivated tourism remains the oldest and most basic reason for mobility in the world. Even each sacred text or holy book of every religion mentions "tourism" or "tourist destination" as a religious activity. In this case, tourist destinations related to spiritual matters become the main tourist destinations for religious reasons or only tourism (CollinsKreiner, 2010).

Humans are always interested in new hobbies, and hence the emergence of inventions and developments in various specialties. There is no exception to visiting new areas because places have different norms, values, and cultures. Certain areas are considered sacred or more special to both certain groups and beliefs. It certainly motivates the individual or group to visit the place, for example, in Islam by visiting Mecca and Medina, Christianity and Judaism by visiting Jerusalem, Catholic by visiting the Vatican,
Hinduism with Benares and Tirupati, Buddhism with Bodh Gaya, and Lhasa. Those locations are famous for their believers. This religious tourism affects either local and wide (Kim \& King, 2019). Religion can be motivated by people traveling to go out of their environment due to historical, religious benefits, and spiritual reasons. The origins of tourism are rooted in religious activities (Griffin \& Raj, 2017). Tourism is now considered a necessity and new in modern society and increases the quality of life and economy. It certainly impacts the needs and behavior of tourists, such as influencing the choice of destination, desired tourism products, and even reaching the point where tourists need special needs to relativity facilities. Thus, religion affects tourism.

\section{Tourism in Islam and the Concept of Muslim Friendly Tourism}

Islam practices and advises tourism in the Quran. Religious activities such as Hajj, Umrah belong to tourism in Islam (Edbiz, 2012) even though Qur'an does not mention them as tourism. Still, this activity is part of religious activities to fulfill spirituality or even completed the Five Pillars in Islam. Hajj and Umrah are spiritual tourism where Muslims visit Mecca 
and Medina. Mecca and Medina are two cities with a historical and religious appeal for Muslims. Hajj and Umrah, are mentioned in Surah Ali Imron/3: 96-97:

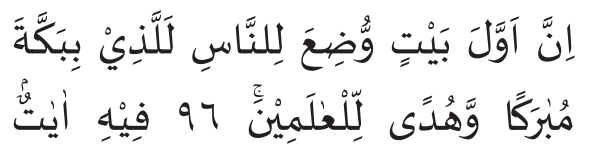

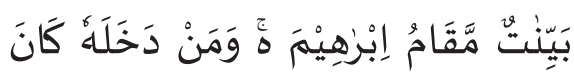

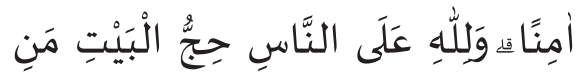

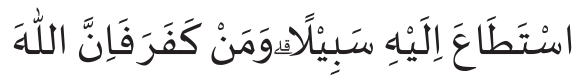

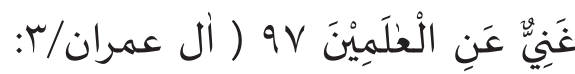
$(9 \vee-97$

96. Indeed, the first House [of worship] established for mankind was that at Makkah - blessed and a guidance for the worlds. 97. In it are clear signs [such as] the standing place of Abraham. And whoever enters it shall be safe. And [due] to Allah from the people is a pilgrimage to the House - for whoever is able to find thereto a way. But whoever disbelieves - then indeed, Allah is free from need of the worlds. (Ali' Imran/3:96-97)

Traveling in Islam is not always about Hajj or Umrah, but can be aimed at leisure or other activities and purpose. The Qur'an says that Islam sees tourism as the greatness of Allah SWT and everything in the world. These actions are also a reminder and fulfill the spiritual need for Muslims. In Qur'an, Muslims are advised to travel as a form of seeing the greatness of Allah SWT as depicted in Surah Al Ankabut/29:20:

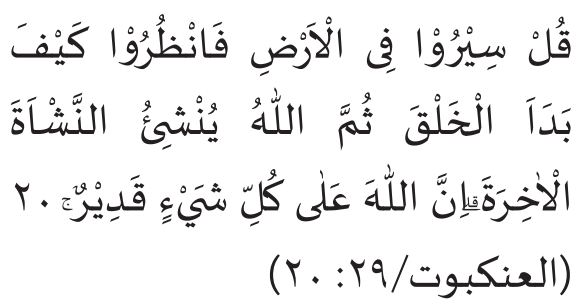

20. Say, [O Muhammad], "Travel through the land and observe how He began creation. Then Allah will produce the final creation. Indeed Allah, over all things, is competent." (Al-'Ankabut/29:20)

Besides, as a reminder, and to fulfill the spiritual need for Muslims, Surah Fusilat/41:53 states that:

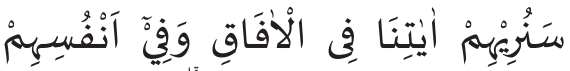

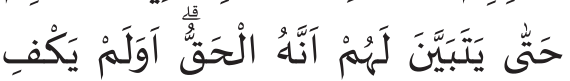

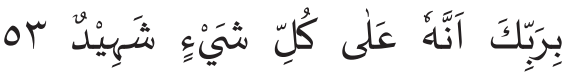

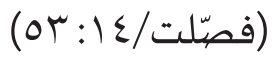

53. We will show them Our signs in the horizons and within themselves until it becomes clear to them that it is the truth. But is it not sufficient concerning your Lord that He is, over all things, a Witness? (Fussilat/41:53) 
Tourism in Islam is unique. The Qur'an as a guide for Muslims indirectly tells Muslims to explore what is on earth as part of worship to Allah SWT. The relationship between tourism, religion, and individuals in Islam also raises new things that primarily fulfill the basic needs. The needs are mentioned as basic needs between the identity from the tourists and availability to meet the needs of tourist destinations. In Islam, all matters have been regulated.

The concept of Muslim-friendly tourism is a complex social activity because it deals with individuals or groups as a whole (Soekadijo, 2000). After all, some individuals or groups will carry their identity and needs. Indeed, this situation will affect the conditions of the local environment. Muslim-friendly tourism is also known as Islamic Tourism, Halal Friendly Tourism Destination, Halal Travel, Muslim-Friendly Travel Destinations (SESRIC, 2017). This name is undoubtedly related to Muslim travelers. According to the Organization of Islamic Cooperation (OIC), Islamic tourism mainly targets Muslims. However, it could also have a universal appeal even for nonMuslims for many reasons like fair pricing, peace and security, familyfriendly environment, and hygiene (SESRIC, 2017).
The other definition about Islamic Tourism from The Standing Committee for Economic and Commercial Cooperation of the Organization of the Islamic Cooperation or COMCEC is tourism by following per under Islam, involving people of the Muslim faith interested in keeping with their religious habits while traveling (COMCEC, 2016). From this understanding, a Muslim must fulfill their need for spirituality as a form of obedience to Islam by traveling.

The simply main point of Muslim-friendly tourism destinations is the availability to fulfill the basic needs of Muslim tourists. Muslims are allowed to travel as long as facilities and services based on Islamic values are available. The essential requirement in a friendly Muslim tourism destination is a pleasant hotel with Muslims by providing halal food and prayer.

\section{Tourism in Japan and Muslim Tourist}

Japan is perfect for tourism management and also its services. Omotenashi focuses on politeness and kindness with relationships with customers or guests by presenting heartwarming service in Japanese 
culture. Under the MLIT (Ministry of Land, Infrastructure, Transport, and Tourism), Japan has a particular organization to promote and develop Japanese tourism, domestic and worldwide, called Japan National Tourism Organization (JNTO). Since its establishment in 1964, JNTO has had 20 offices spread throughout the world.

Japanese Prime Minister Shinzo Abe uses tourism in Abenomics, and this policy their economic policy during the reign of Shinzo Abe. Abenomics targets that in 2020 Japan will have had 40 million tourists coming to Japan to earn an income of 8 trillion yen, and in 2030 will attract 60 million tourists with 15 trillion yen income.

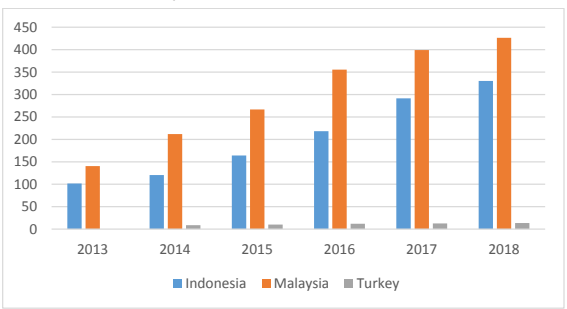

Table 1. Japan visitors with Tourism Purpose (JNTO, 2020)

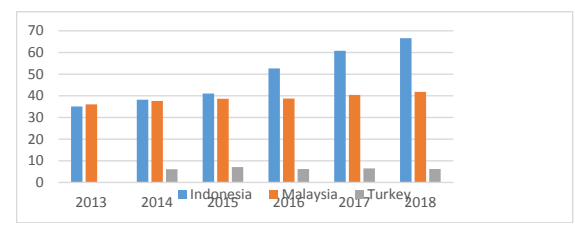

Table 2. Japan visitors with Commercial and Other Purpose (JNTO, 2020)
Japan keeps developing further for service, facilities, and some policies. The Japanese government, since 2013, provides facilities in making visas for tourists who come from Southeast Asia to visit Japan, of course. This step was taken to attract tourists from Southeast Asia. Southeast Asia consists of developing countries with a middle-class economy. This situation does not exclude the possibility for Muslim tourists from Malaysia, Indonesia, and Brunei, predominantly Muslims, to travel to Japan, especially Indonesia as a country with one of the most populations globally, with $80 \%$ of the population Muslim. In 2016, 121 million Muslim tourists were coming to Japan and grew to 156 million by 2020 , where the travel expenditure by Muslim tourists is expected to reach USD 220 billion. It is also projected that the total Muslim travel expenditure will reach USD 300 Billion by 2026 (Crescentrating, 2017).

Japan is famous for having good quality products or unique characteristics. The Japanese government is increasing the number of foreign tourists by implementing a tax-free policy for tourists visiting Japan. This tax-free policy will undoubtedly increase the 
level of tourists to shop. In this case, it will indeed affect income in the Japanese economy. According to the Japan Muslim Travel Index (JMTI), in 2016, international Muslim tourists visited Japan were 700,000 and increased to $1,400,000$ Muslim tourists by 2020 .

Muslim-friendly tourism has become a new phenomenon in the world of tourism and brought needs and services. Muslim-friendly tourism depends on Muslim tourists' needs once they are met. The availability of halal food and places to salat is Muslim tourists' basic needs. Muslims only eat halal food as listed in the Qur'an and Hadith. Furthermore, in serving halal food and beverages, cooking utensils must also be separated from non-halal.

\section{Challenges and Case Studies}

\section{Food Sign}

Being a Muslim when traveling to a non-Muslim country, consuming halal or Muslim-friendly food is an option to avoid illicit food prohibited in Islam. Muslim travelers somehow should adjust according to the conditions. Therefore, information and accessible WIFI services for tourists are undoubtedly beneficial to find restaurants for Muslim travelers.
Giving pictures and the inclusion of cooking ingredients for a Muslim has been helpful in a country with a majority of nonMuslims. It is also beneficial for other tourists even though nonMuslims indirectly learn the dish component or have an allergy. Another issue is language constraint because not all tourists understand Japanese, and not many Japanese people can speak English. It will be helpful when the restaurants have a halal label to avoid communication fails.

Prayer room and wudu, we will stay longer in your places!

Salat is obligatory for Muslims. A prayer room is a place for prayer and an area with educational, social, administrative, and preventative functions. Therefore, it must be clean. Lack of understanding of halal means that worship provided does not have boundaries, and men and women must be separated. Also, another critical aspect closely related to prayer is wudu. It is an activity of purification. Business people in Japan have been aware of halal food and salat for Muslims. Some places have provided prayer rooms, but not wudu space.

\section{Halal Sign}

Providing a logo or symbol 
related to halal food or product ingredients will certainly be a solution to cover these shortcomings and as a form of additional service. Having a halal sign will also increase the trust of the restaurant between restaurants and customers. A halal sign will attract Muslim tourists, and non-Muslim tourists can also try halal cuisines. It can also affect locals to learn more about Islam. Lack of knowledge of halal products and food may also create problems. The restaurants put self-claimed logos or halal under illegal halal institutions. Hence, socialization related to halal products and food also needs to be a concern.

\section{Language}

Japan is a country with a high nationalism, so only a few Japanese can speak foreign languages, especially English. Language in Japan is a fundamental problem. Instructions and information in English are limited. Some tourists may make this a complaint and an obstacle. Little English instructions make it difficult for Muslim tourists to decide whether the food is halal.

\section{CONCLUSION}

Travel tourism has been part of people's lives. Accessible information and technology make human mobility faster. Consciously, each religion has a role in tourism, seen from the pilgrimages. In Islam, traveling has its benefits and purposes for Muslims, as mentioned in Surah Ali Imron/3: 96-97, Al Ankabut/29:20, and Fusilat/41:53. The primary traveling needs are to ensure that each is fulfilled. Travelers should consider carefully how the destinations can fulfill their needs.

Muslim tourists or travelers have the exact needs as other tourists, but more specifically, following Islamic teachings such as having halal food and a prayer room. It would be better if the places also provide wudu space and understand about Ramadan. Non-Muslim tourists can also take benefits from the services if they want to avoid casinos or pubs. Muslim tourists, in general, will significantly appreciate the destinations when they can help meet their needs. It also can be a soft promotion and image branding for tourist destinations. Through SNS, Muslim tourists will help spread and promote halal services and facilities provided to the world.

\section{REFERENCES}

Charles R. Goeldner, J. B. (2009). Tourism Principles, Practices, Philosophies. New Jersey: John Wiley \& Sons, INC. 
Collins-Kreiner, N. (2010). R E S E A R C H I N G PILGRIMAGE Continuity and Transformations. Annals of Tourism Research, Vol. 37, 440-456.

COMCEC. (2016). Muslim friendly Tourism: developing and marketing MFT products and services in the OIC member countries. Ankara: COMCEC COORDINATION OFFICE.

Crescentrating, M. A. (2017). Global Muslim Travel Index 2017. Singapore: Mastercard \& Crescentrating.

Dallen J. Timothy, D. H. (2006). Tourism, Religion and Spiritual Journeys. New York: Routledge.

Edbiz. (2012). The Global Halal Industry: An Overview. NASDAQ OMX GLOBAL INDEXES. 13, 140-158.

Griffin, K., \& Raj, R. (2017). The Importance of Religious Tourism and Pilgrimage: Reflecting on Definitions, Motives, and Data. International Journal of Religious Tourism and Pilgrimage. 5, 2-9.

JNTO. (2020). Data on the number of foreign visitors to Japan and the number of Japanese leaving Japan. Retrieved from JNTO: https://www.jnto.go.jp/jpn/ statistics/tourists_2019df.pdf

Kim, B., \& King, B. E. (2019). Religious tourism studies: evolution, progress, and future prospects. Tourism Recreation Research, 185-203.

Kreiner, N. C., \& Wall, G. (2015). Tourism and Religion: Spiritual Journeys and Their Consequences. The Changing World Religion Map: Sacred Places, Identities, Practices, and Politics. 2, 689-707.

Ma, I. (2018, October 7). Halal market in China: Potentials and Challenges. Retrieved from UMEXPERT: https:// umexpert.um.edu.my/file/ publication/00008283_103505. pdf

Namin, T. (2013). Value Creation in Tourism: An Islamic Approach. International Research Journal of Applied and Basic Sciences. 5, 1252-1264.

Nurdiansyah, A. (2018). Halal Certification and Its Impact on Tourism in Southeast Asia: A Case Study Halal Tourism in Thailand. KnE Social Sciences, 26-43.

Palupi, M., Romadhon, R. W., \& Arifian, N. (2017). Importance of Optimization of Halal 
Tourism: A Study of The Development of Halal Tourism in Indonesia. Conference Paper, $1-10$.

Peace, I. f. (2019). Global Peace Index 2019: Measuring Peace in a Complex World. Sydney: Institue for Economics \& Peace. Razzaq, S., Hall, C. M., \& Prayag, G. (2016). The capacity of New Zealand to accommodate the halal tourism market - or not. Tourism Management Perspectives. 18, 89-107.

SESRIC. (2017). Strategic roadmap for development of islamic tourism in oic member countries. Ankara: The Statistical, Economic and Social Research and Training Centre for Islamic Countries (SESRIC).

Soekadijo, R. (2000). Anatomi Pariwisata Memahami Pariwisata sebagai System Linkage. Jakarta: PT Gramedia Pustaka Utama.

Surwandono, Nursita, R. D., Diana, R., \& Meiliyana, A. (2020). Polemik Kebijakan Wisata Halal di Indonesia serta Tinjauannya dalam Maqashid Syariah. TSAQAFAH Jurnal Peradaban Islam. 16, 91-108.
Thomson Reuters, D. S. (2016). State of the Global Islam Economy Report 2016/17. Dubai: Thomson Reuters. 